\title{
İş Doyumunun Sanal Kaytarma Davranışı Üzerindeki Etkisi: Gaziantep İlinde Özel Sektörde Çalışanlar Üzerinde Bir Araştırma \\ (The Effect of Job Satisfaction on Cyberloafing Behaviour: A Research on Private Sector Employees in Gaziantep)
}

\author{
Cafer Şafak EYEL iD a Alper TUTCU iD b \\ a Bahçeşehir Üniversitesi, Sosyal Bilimler Enstitüsü, İstanbul, Türkiye. safakeyel@gmail.com \\ b Hasan Kalyoncu Üniversitesi, Sosyal Bilimler Enstitüsü, Gaziantep, Türkiye. alpertutcu@hotmail.com
}

\begin{tabular}{|c|c|}
\hline MAKALE BİLGİSI & ÖZET \\
\hline Anahtar Kelimeler: & aç - Teknolojide yaşanan gelişmelerle birlikte internet günlük hayatın önemli bir parçası durumuna \\
\hline İş Doyumu & Imiştir. Ancak internetin yaygınlaşması ve işletmelerde de yoğun şekilde kullanılmaya başlanması \\
\hline Sanal Kaytarma & $\begin{array}{l}\text { ticesinde çalışan bireylerin iş yerinde sanal kaytarma davranışında bulunmaya başladıkları } \\
\text { rülmüștür. Calışanları sanal kaytarma davranışı sergilemeye yönlendiren pek çok faktör }\end{array}$ \\
\hline Arama Yapma & lunmaktadır. Bu çalışma çerçevesinde iş doyumunun sanal kaytarma davranışı üzerinde etkisi olup \\
\hline Haber Takibi & 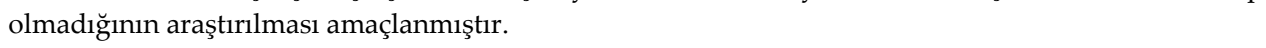 \\
\hline Bireysel İşler & $\begin{array}{l}\text { Yöntem - Araştırma kapsamında bir anket formu oluşturularak, } 21 \text { Nisan } 2019 \text { ile } 17 \text { Temmuz } 2019 \\
\text { tarihleri arasında Gaziantep ilinde özel sektörde çalışan } 413 \text { kişi üzerinde anket uygulaması } \\
\text { gerçekleştirilmiştir. Çalışanların iş doyumlarını ölçmek üzere Brayfield ve Rothe (1951) tarafından } \\
\text { geliştirilen, Yoon ve Thye (2002) tarafından kısaltılan, Kuşluvan ve Kuşluvan (2005) tarafından Türkçe }\end{array}$ \\
\hline $\begin{array}{l}\text { Gönderilme Tarihi } 16 \text { Mayıs } \\
2020\end{array}$ & $\begin{array}{l}\text { diline uyarlanan } 5 \text { maddelik iş doyumu ölçeği kullanılmıştır. Çalışanların siber aylaklık davranışlarını } \\
\text { ölçmek üzere ise Blanchard ve Henle (2008) tarafından geliştirilen, Kalaycı (2010) tarafından Türkçe }\end{array}$ \\
\hline Revizyon Tarihi 10 Ekim 2020 & diline uyarlanan, 23 madde ve 4 boyuttan meydana gelen Sanal Kaytarma Davranışı Ölçeği \\
\hline Kabul Tarihi 13 Kasım 2020 & $\begin{array}{l}\text { kullanılmıştır. Elde edilen veriler SPSS-22 programı aracılı̆̆ıyla analiz edilmiştir. Bu doğrultuda, faktör } \\
\text { analizi, güvenilirlik analizi, regresyon analizi, Bağımsız Örneklem T Testi ve ANOVA Testi } \\
\text { kullanılmıștır. }\end{array}$ \\
\hline
\end{tabular}

Bulgular - Sanal kaytarma davranıșı ölçeği üzerinde gerçekleştirilen faktör analizi neticesinde; arama yapma, bireysel işler, sosyalleşme ve haber takibi şeklinde isimlendirilen 4 faktör tespit edilmiştir.

Makale Kategorisi: Araştırma Makalesi Çalışmanın ana amacı doğrultusunda gerçekleştirilen hipotez testleri neticesinde; iş doyumunun sanal kaytarma davranışı faktörleri üzerinde anlamlı bir etkiye sahip olmadığı tespit edilmiştir. Bununla birlikte, sanal kaytarma davranışı faktörleri ve iş doyumuna verilmiş olan yanıtların, katılımcıların çeşitli demografik özelliklerine göre farklılaşmakta olduğu bulgusu elde edilmiştir.

Tartışma - İş doyumunun sanal kaytarma davranışı üzerinde anlamlı etkisi olmadığına ilişkin bulgunun, literatürdeki önceki çalışmaların bulgularıyla genel olarak paralellik göstermediği saptanmıştır. İş doyumunun sanal kaytarma davranışı faktörleri üzerinde anlamlı etkiye sahip olmamasının nedeni ise, internet kullanımının gündelik yaşamda ve iş yaşamında artık normal bir davranış şeklinde algılanıyor olması biçiminde değerlendirilmiştir.

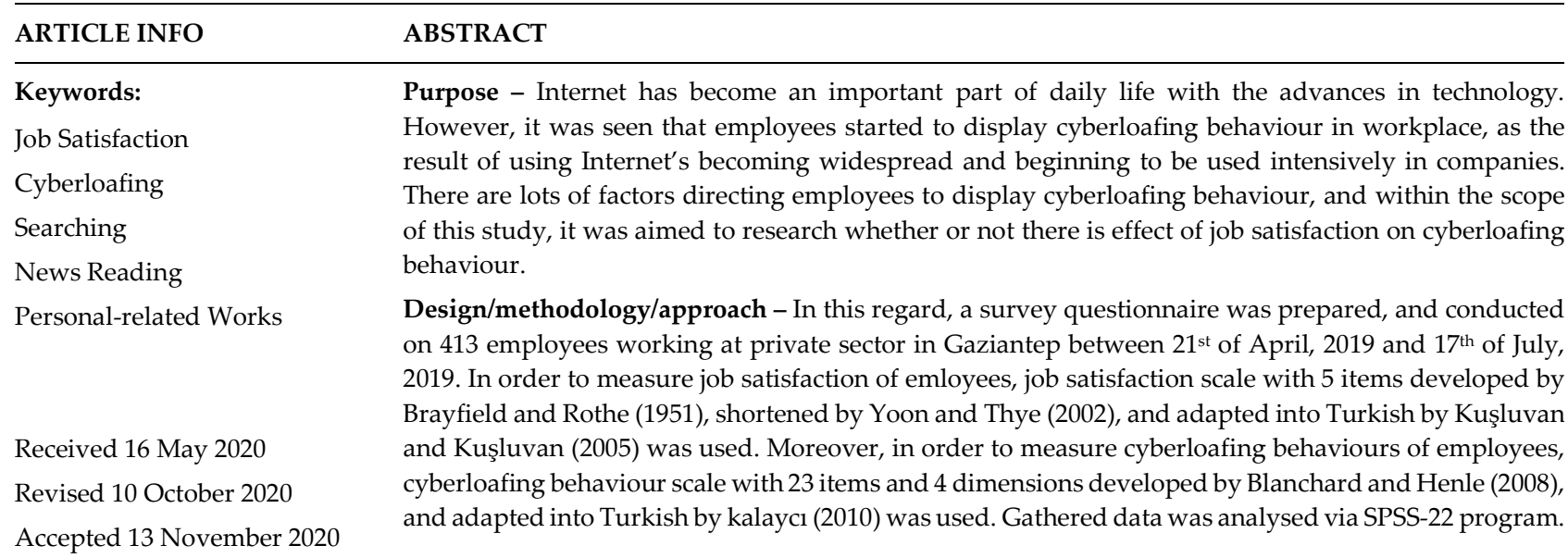

\section{Önerilen Atıf/Suggested Citation}

Eyel, C., Ş., Tutcu, A. (2020). İş Doyumunun Sanal Kaytarma Davranışı Üzerindeki Etkisi: Gaziantep İlinde Özel Sektörde Çalışanlar Üzerinde Bir Araştırma, İsletme Araştırmaları Dergisi, 12 (4), 3596-3612. 
In this regard, factor analysis, reliability analysis, regression analysis, Independent Samples T Test and ANOVA Test were used.

Article Classification:

Research Article
Findings - As the result of factor analysis conducted for cyberloafing behaviour scale, there were determined 4 factors named as searching, personal-related works, socialization and news reading. Furthermore, as the result of hypothesis tests made in context to the main goal of the study, it was found that job satisfaction does not have significant effect on cyberloafing behaviour factors. Moreover, the finding that the responses given for cyberloafing behaviour factors and job satisfaction are different according to some demographical features of participants, was reached.

Discussion - There was determined that the finding indicating there is no significant effect of job satisfaction on cyberloafing behaviour is not is parallel with the findings of previous studies in the literature. Moreover, the reason that job satisfaction does not have effect on cyberloafing behaviour was evaluated as the use of Internet's to be perceived as a normal behaviour in both daily life and job life.

\section{Giriş}

1990'lı ve 2000'li yıllarda bilgi ve iletişim teknolojilerinde oldukça büyük değişimler ve dönüşümler gerçekleşmiştir. Bu doğrultuda ortaya çıkan en önemli sonuçlardan birisi, internetin hem bireyler arasında hem de işletmelerde yaygın şekilde kullanılır hale gelmesi olmuştur. Her ne kadar bu yeni teknoloji insanların gündelik yaşamlarını kolaylaştırsa ve işletmelerin daha hızlı ve etkili şekilde çalışmasını sağlasa da, internet dünyasının büyümesi ve kullanımının artması neticesinde işletmeler açısından genel olarak olumsuz bir durum şeklinde nitelendirilen sanal kaytarma davranışı ortaya çıkmıştır. Zira çalışanlar, iş yerinde yapmaları gereken işleri yaparken, aynı zamanda interneti kullanarak iş dışı birtakım aktivitelerde bulunabilmektedir. Bu davranışın sergilenmesi hususunda etkili olan pek çok unsur bulunmakla birlikte, pek çok araştırmada iş doyumsuzluğunun sanal kaytarma davranışına neden olduğu belirtilmiştir (Yıldırım, 2018; Çivilidă̆, 2017; Çavuşoğlu ve Palamutçuoğlu, 2017; Cook, 2017; Chaudhuri ve Naskar, 2014; Chomal ve Baruah, 2014; Folami vd., 2014; Alias vd., 2013; Robbins ve Judge, 2013; Özler ve Polat, 2012; Vitak vd., 2011; Garrett ve Danziger, 2008; Manrique de Lara vd., 2006; Stanton, 2002). Bu doğrultuda bu çalışmada da Gaziantep ilinde özel sektörde çalışanların iş doyumlarının sanal kaytarma davranışı üzerinde etkisinin bulunup bulunmadığının incelenmesi amaçlanmıştır. Belirtildiği üzere ulusal ve uluslararası literatürde bu konu hakkında yapılmış olan çeşitli çalışmalar mevcuttur. Ancak ülkemizde konuya ilişkin yapılmış araştırma sayısı az olup, Gaziantep ilindeki özel sektör çalışanları üzerinde de bu tür bir araştırmanın yapılmamış olduğu tespit edilmemiştir. Bu nedenle, bu çalışmada elde edilecek olan bulguların sanal kaytarma literatürüne önemli bir katkı sağlayacağı öngörülmektedir. Ayrıca araştırma bulgularının, Gaziantep ilindeki özel sektör firmalarına sanal kaytarma ile iş doyumu arasındaki ilişkiyi göstermesi bakımından da çalıma önemliliğe sahiptir.

\section{KAVRAMSAL ÇERÇEVE}

Çalışmanın bu bölümünde iş doyumu ve sanal kaytarma davranışına ilişkin kavramsal çerçeve sunulmuş ve iş doyumu ile sanal kaytarma davranışı ilişkisine yönelik literatürde önceden yapılmış olan çalışmaların bulgularına yer verilmiştir.

\section{1. İs Doyumu}

İşgörenler çalışma yaşamları süresince yaptıkları işler, çalıştıkları örgütler ve çalışma ortamı ile alakalı birçok tecrübe edinmektedir. Bu tecrübeler neticesinde elde ettikleri bilgilerle duygular neticesinde işgörenlerin yaptıkları işe veya çalıştıkları işletmeye yönelik tutumları ortaya çıkmaktadır. Bu tutumların genel sonucu da iş doyumu olarak nitelendirilmektedir (Taş, 2011: 120-121).

Locke (1968: 10) iş doyumunun, çalışana zevk vermekte olan bir duygusal durum olduğuna değinmiş olup, bu duygusal durum da çalışanın işine atfettiği değeri elde etmesinin sonucu olarak pozitif ya da negatif biçimde değerlendirmesinden kaynaklanmaktadır. Bu bağlamda iş doyumu veya doyumsuzluğu da çalışanın işinden ne istediği ve beklediği ile gerçekleştirdiği işin sonucu olarak algılamakta olduğu değerin arasında bulunan ilişkinin bir fonksiyonu şeklinde tanımlanabilir. Greenberg ve Baron (2003: 170) ise iş doyumunu, işgörenlerin işlerine yönelik genel tutumu olarak değerlendirmiştir. Bununla birlikte Türk (2007: 67) iş doyumunun, çalışan kişinin icra ettiği vazifenin ve bu neticede elde ettiklerinin, gereksinimleriyle ve kişisel değer yargıları ile örtüşmesine olanak tanıdığını fark etmesinin neticesinde yaşadığı pozitif duygu olduğundan bahsetmiştir. 


\section{C. Ş. Eyel - A. Tutcu 12/4 (2020) 3596-3612}

Günümüz koşullarında iş doyumunun öneminin gittikçe artmakta olduğu söylenebilir. Nitekim bu noktada iki temel neden belirmektedir. Birinci neden, çalışanın fiziksel ve ruhsal sağlığını direkt olarak etkileyen yaşam doyumuyken; ikinci neden, üretkenlikle ilintilidir. İş doyumsuzluğunun sonucu olarak ortaya çıkan stres, tükenmişlik, uyumsuzluk gibi dolaylı etkenler çalışanı negatif yönlü olarak etkilemekteyken, işgörenin çalışma performansının da düşmesine sebebiyet vermektedir (Aşık, 2010: 32). İş doyumsuzluğunun önemli birtakım bireysel neticeleri mevcuttur. Stres, tükenmişlik ve uyumsuzluğa ek olarak çalışan kişinin işiyle kendisine yabancılaşması, yetersizlik duygusuna sahip olma, diğer çalışanlarla iş birliği yapamama, işinde hata yapma, tutarsız kararlar alma, verimsizlik, işten ayrılma, işe devamsızlık, bıkkınlık gibi negatif sonuçlar ortaya çıkabilmektedir (Şimşek vd., 2007: 585).

İşgörenlerin yüksek bir iş doyumuyla vazifelerini görmeleri, işletmenin gerçekleştirdiği faaliyetlerde verimliliğin artmasını sağlar. İş doyumu yüksek düzeyde olan işgörenler, çalışma ortamında pozitif birtakım davranışlar sergilerler. İşinden doyum alamayan işgörenler ise çalışma ortamında her an negatif davranışlarda bulunma eğilimindedir. Bu doğrultuda iş doyumsuzluğu; ani grevler, iş yavaşlatma, düşük verimlilik, disiplin sorunları vb. örgütsel problemlerin kaynağını teşkil etmektedir (Barlı, 2008: 345).

\subsection{Sanal Kaytarma}

Günümüz iş hayatında insan unsuru, bilgi ve iletişim teknolojilerinde yaşanan tüm yeniliklere ve gelişimlere karşın halen oldukça önemlidir. Ancak teknoloji alanında yaşanan bu yeniliklerle gelişimlerin işgörenlerin hem iş yaşamlarında hem de gündelik yaşamlarında sergiledikleri davranışlar üzerinde önem arz eden etkilerinin bulunduğu söylenebilir. İster üretim ister hizmet sektöründe olsun, günümüz koşullarında özellikle masa başında çalışan beyaz yakalı işgörenler açısından internet, bilgisayar ve mobil telefonlar işletmedeki işlerin gerçekleştirilmesi hususunda faydalanılan vazgeçilemez araçlar durumuna gelmiştir. Nitekim internetin işletmelerde yaygın şekilde kullanılması, işletme masraflarının azalmasını, bilgiye erişimin hızlanmasını, küresel çapta iletişimin gelişmesini, pazarlama ile üretimde etkinliğin ve hızlılığın elde edilmesini sağlamış durumdadır (Liberman vd., 2011: 2192). Ancak her ne kadar internetin iş dünyasına sağladığı pozitif katkılar olsa da, negatif birtakım etkilerinin bulunduğundan da bahsedilebilir. Bu olumsuzluklar arasında işgörenlerin özel hayat endişeleri, işgörenlerin internette gerçekleştirdikleri faaliyetlerden kaynaklanmakta olan üretim ve etkililik azalması gösterilebilir (Lim ve Teo, 2005: 1081-1082).

İnternetin iş dünyasına getirmiş olduğu olumsuz bir durum olan sanal kaytarma Lim'e (2002: 677) göre, iş yerinde işgörenin performans seviyesini azaltmakta olan üretim karşıtı sapkın bir davranıştır. Ü̈̆ ve Tekdemir (2015: 95) sanal kaytarmanın; işgörenlerin çalışma ortamında kişisel internet kullanımı, kişisel epostaları kontrol etme, haberlere göz atmaktan; müstehcen içeriğe sahip web sitelerini ziyaret etme, diğer çalışanlara cinsel içerikli mesajlar gönderme ya da yasal olmayan yollar üzerinden program indirmeye değin oldukça geniş bir yelpazedeki eylemlerden meydana geldiğini belirtmiştir. Bunun yanı sıra Weatherbee (2010) sanal kaytarmayı mesai saatleri sırasında oyun oynama, eğlenme maksatlı olarak web sitelerine ziyarette bulunma, kişisel e-postaları kontrol etme biçiminde gerçekleşen davranışlar şeklinde betimlerken; Blanchard ve Henle (2008) ise sanal kaytarmayı, işgörenin yaratıcılı̆̆ını arttırabileceği, olayları farklı açılardan inceleyip öğrenme fırsatı ve esneklik kazandırabilecek olumlu bir davranış şeklinde ifade etmiştir.

Sanal kaytarmaya ilişkin ilk çalışmayı literatürde Lim (2002) gerçekleştirmiş olup, Lim (2002) sanal kaytarmayı e-posta üzerinden gerçekleştirilmekte olan sanal kaytarma durumu ve web sitesi kullanımı üzerinden gerçekleştirilmekte olan sanal kaytarma durumu şeklinde iki gruba ayırmıştır. Anandarajan vd. (2004) iş yerinde üç tür sanal kaytarma davranışı olduğundan söz etmiş ve bunları; zarar verici ya da bozucu sanal kaytarma, yaratıcı ve boş zamanları doldurucu sanal kaytarma, öğretici sanal kaytarma şeklinde isimlendirmiştir. Blanchard ve Henle (2008) sanal kaytarmanın farklı formlarının bulunduğundan bahsederek, sanal kaytarma davranışlarını önemsiz sanal kaytarma ve önemli sanal kaytarma şeklinde iki boyutta incelemiştir. Bu arada önemsiz sanal kaytarma e-posta kullanımı, genel haber sitelerine, finansal ve spor sitelere bakma, çevrimiçi alışveriş gerçekleştirme, açı artırma sitelerine girme ile ilgiliyken; önemli sanal kaytarma ise kumar sitelerine girme, blog okuma, müzik indirme, kişisel web sayfasını düzenleme, sohbet odalarına girme ile alakalıdır. İnce ve Gül (2010) ise sanal kaytarma davranışlarını şu şekilde gruplandırmıştır:

- Kişi ya da kuruluş bakımından zararlı ya da zararsız olması açısından zararlı sanal kaytarma ve zararsız sanal kaytarma,

- Sonuçlar ve etkiler açısından önemsiz sanal kaytarma ve önemli sanal kaytarma, 
- Etik olması ya da olmaması bakımından ahlaki sanal kaytarma ve ahlaksız sanal kaytarma,

- Yasal zorunluluktan ötürü ya da zorunluluk dışı olması bakımından yasal sanal kaytarma ve yasadışı sanal kaytarma,

- Zaman harcama açısından kısa süreli sanal kaytarma ve uzun süreli sanal kaytarma,

- Yönetici politikaları bakımından sanal kaytarma ile mücadele gerekliliği ve sanal kaytarmaya tolerans gösterme gerekliliğ̈i.

\section{3. Önceki Çalışmalar}

İşgörenlerin işlerine karşı negatif bir tutuma sahip olması, sanal kaytarma davranışında bulunmalarına neden olabilmektedir (Manrique de Lara vd., 2006: 451-452). Nitekim çalışanların iş doyumlarının düşüklügüu, örgütler açısından verimsizlik, performans düşüklüğü gibi olumsuzluklara sebebiyet verebilecek davranışların sergilenmesine sebebiyet verebilmektedir (Robbins ve Judge, 2013: 87). Bu doğrultuda çeşitli araştırmalar (Özler ve Polat, 2012: 9; Garrett ve Danziger, 2008: 939) işgörenlerin çalışma ortamında interneti iş dışında kişisel maksatlı olarak kullanmalarının nedenleri arasında iş tatminindeki düşüklügün de bulunduğundan bahsetmektedir. Buna ek olarak, literatürdeki pek çok çalışmada iş doyumu ile sanal kaytarma davranışı arasında anlamlı ve negatif yönlü ilişkiler bulunduğu tespit edilmiştir (Cook, 2017; Chaudhuri ve Naskar, 2014; Chomal ve Baruah, 2014; Folami vd., 2014; Alias vd., 2013; Vitak vd., 2011; Stanton, 2002).

Yurt dışında iş doyumu ile sanal kaytarma ilişkisine yönelik pek çok çalışma yapılmış olduğu gibi, Türkiye'de de konuya ilişkin bazı araştırmalar yapılmış durumdadır. Çivilidağ (2017) tarafından yapılan çalışmada Antalya ilinde hizmet sektöründe (bankacilık, otomotiv, turizm) çalışanlarda sanal kaytarma davranışı, iş stresi ve iş doyumu incelenmiştir. Yapılan araştırmada, iş doyumunun önemli sanal kaytarma davranışını anlamlı şekilde etkilediği saptanmıştır. Çavuşoğlu ve Palamutçuoğlu (2017) tarafından yapılan çalışmada, Manisa Celal Bayar Üniversitesi akademik ve idari personeli üzerinde, iş tatmininin sanal kaytarma davranışı üzerindeki etkisi incelenmiştir. Çalışmanın bulgularına göre, iş tatmininin sanal kaytarmayı negatif yönlü olarak etkilediği tespit edilmiştir. Yıldırım (2018) tarafından yapılan çalışmada Erzurum ilinde faaliyet gösteren serbest muhasebeci mali müşavirlerde, tükenmişliğin sanal kaytarma davranışına etkisinde iş doyumunun aracı rolü incelenmiştir. Araştırma neticesinde, iş doyumunun önemli sanal kaytarma ile negatif yönlü bir ilişkisi olduğu bulgusu elde edilmiştir. Yılmaz (2018) tarafından Eskişehir'de seyahat acentesinde çalışanlar üzerinde yapılan çalışmada sanal kaytarma davranışı, iş motivasyonu ve iş tatmini arasındaki ilişkiler incelenmiştir. Yapılan analizler neticesinde, sanal kaytarma ile iş tatmini arasında anlamlı bir ilişkiye rastlanmamıştır.

\section{YÖNTEM}

Bu bölümde araştırmanın evreni ve örneklemi tanıtılmış, verilerin toplanmasında kullanılan teknik ve veri toplama aracı ile verilerin analiz yönteminden bahsedilerek, veri toplama araçlarının geçerlilik ve güvenilirlik analizlerine yer verilmiş, bu doğrultuda oluşan araştırma modeli ve hipotezleri hakkında bilgiler verilmiştir.

\subsection{Evren ve Örneklem}

Bu araştırmanın genel evrenini, Türkiye' deki özel sektör çalışanları teşkil etmektedir. Çalışma evreni olarak Gaziantep ili seçilmiş ve bu doğrultuda Gaziantep ilinde çalışan 413 özel sektör çalışanı anket çalışması gerçekleştirilmiştir. Gaziantep ilinin seçilmesinde, bu ilde çalışanlar özelinde daha önce iş doyumu ve sanal kaytarma davranışı ilişkisine yönelik bir araştırmanın yapılmamış olması ve araştırmacılardan birinin Gaziantep ilinde yaşıyor ve çalışıyor olması etkili olmuştur. Örnekleme tekniği olarak kolayda örnekleme kullanılmıştır. Bu doğrultuda, yüz yüze anket ve online anket uygulaması aracılığıyla, 21 Nisan 2019 ile 17 Temmuz 2019 tarihleri arasında uygulama gerçekleştirilmiştir.

\subsection{Verilerin Toplanması ve Analizi}

Araştırma çerçevesinde birinci elden veri toplamak üzere anket tekniğinden faydalanılmış ve araştırmacılar tarafından üç bölümden meydana gelen bir anket formu oluşturulmuştur. Yapılan uygulama neticesinde elde edilen bulgular SPSS-22 bilgisayar programı vasıtasıyla analiz edilmiştir. Bu hususta frekans tabloları, tanımlayıcı istatistikler, faktör analizi, güvenilirlik analizi, basit doğrusal regresyon analizi, Bağımsız Örneklem T Testi ve ANOVA Testi'nden faydalanılmıştır. 
Anket formunun ilk bölümü olan Kişisel Bilgi Formu'nda katılımcıların cinsiyetlerini, medeni durumlarını, yaş gruplarını, eğitim düzeylerini ve aylık gelir durumlarını tespit etmek üzere beş soru bulunmaktadır.

Anketin ikinci bölümünde Brayfield ve Rothe (1951) tarafından geliştirilip Yoon ve Thye (2002) tarafından kısaltılan, Kuşluvan ve Kuşluvan (2005) tarafından Türkçe diline uyarlanan İş Doyumu Ölçeği yer almaktadır. Ölçek 5 madde ve tek boyuttan meydana gelmektedir ve her bir madde 5'li Likert Sistemi ile ölçülmektedir. Ölçekte yer alan beşinci madde ters ifade niteliğinde olup, veri analizi sürecinde olumluya çevrilerek değerlendirilmiştir. Tablo 1'de İş Doyumu Ölçeği için gerçekleştirilmiş olan geçerlilik ve güvenilirlik analizlerine ilişin bulgular yansitılmıştır. Tabloda görüldüğü üzere; KMO değeri $(0,841)$ örneklem büyüklüğünün ölçek üzerinde faktör analizi yapmak üzere yeterli olduğunu; Bartlett Küresellik Testi sonucu (Ki-Kare: 1588,939; sd: 10; Sig.: 0,000) ise ölçeğin faktör analizi yapmak üzere uygun olduğunu göstermektedir. Yapılan faktör analizi neticesinde, orijinal ölçekle uyumlu şekilde 5 madde ve tek faktörden oluşan bir yapı elde edilmiştir. Ölçeğin açıklanan varyansı \%73,348'dir. Ölçeğin güvenilirlik düzeyi ise 0,898 ile oldukça yüksektir.

Tablo 1. İş Doyumu Ölçeği İçin Geçerlilik ve Güvenilirlik Analizi Bulguları

\begin{tabular}{|c|c|c|c|}
\hline Kod & İfade & İş Doyumu & Güvenilirlik \\
\hline İD1 & İD2-Genel olarak işimi seviyorum. & 0,925 & \multirow{5}{*}{0,898} \\
\hline İD2 & İD1-Genel olarak işimden memnunum. & 0,907 & \\
\hline İD3 & İD4-İşimden zevk alıyorum. & 0,899 & \\
\hline İD4 & $\begin{array}{l}\text { İD3-Çoğu zaman iyi bir işim olduğunu } \\
\text { düşünüyorum. }\end{array}$ & 0,883 & \\
\hline İD5 & İD5-İşime karşı ilgimi kaybediyorum. & 0,634 & \\
\hline & Açıklanan Varyans & $73,35 \%$ & Toplam $\% 73,348$ \\
\hline \multicolumn{4}{|c|}{ KMO: 0,841; Ki-Kare: 1588,939; sd: 10; Sig.: 0,000 } \\
\hline
\end{tabular}

Anketin üçüncü bölümünde Blanchard ve Henle (2008) tarafından geliştirilen, Kalaycı (2010) tarafından Türkçe diline uyarlanan Sanal Kaytarma Davranışı Ölçeği yer almaktadır. Ölçek 23 madde ve 4 boyuttan meydana gelmektedir. Bu boyutlar; bireysel işler, sosyalleşme, arama yapma ve haber takibi şeklindedir. Ölçekte yer alan 1, 2, 7, 8, 9, 10, 12, 16 ve 17. maddeler bireysel işler; 11, 13, 14, 15, 19 ve 23. maddeler sosyalleşme; 3, 4, 5 ve 6 . maddeler arama yapma ve 18,20 , 21 ve 22 . maddeler haber takibi boyutuna ilişkindir. Ölçekte yer alan maddeler 5'li Likert Sistemi ile ölçülmektedir.

Tablo 2'de Sanal Kaytarma Ölçeği için gerçekleştirilmiş olan geçerlilik ve güvenilirlik analizlerine ilişin bulgular yansıtılmıştır. Tabloda görüldüğü üzere; KMO değeri $(0,861)$ örneklem büyüklüğünün ölçek üzerinde faktör analizi yapmak üzere yeterli olduğunu; Bartlett Küresellik Testi sonucu (Ki-Kare: 2220,840; sd: 105; Sig.: 0,000) ise ölçeğin faktör analizi yapmak üzere uygun olduğunu göstermektedir. Yapılan faktör analizi esnasında en uygun neticelere ulaşmak üzere 8 madde ölçekten çıkarılırken ${ }^{1}$, böylece orijinal ölçekle uyumlu olacak şekilde dört faktörlü bir yapı elde edilmiştir. Bu faktörler, barındırdığı maddeler doğrultusunda sırasıyla arama, bireysel işler, sosyalleşme ve haber takibi şeklinde isimlendirilmiştir. Tablo 2'ye göre ölçeğin açıklanan toplam varyansı \%61,332' dir. Arama yapma faktörü varyansın \%17,91'ini, bireysel işler faktörü varyansın \%14,76'sını, sosyalleşme faktörü varyansın \%14,54'ünü, haber takibi faktörü varyansın \%14,12'sini açıklamaktadır. Tabloda ayrıca her bir faktörün ve ölçeğin güvenilirlik düzeyleri de belirtilmiştir. Buna göre arama yapma faktörünün güvenilirliği 0,817 ; bireysel işler faktörünün güvenilirliği 0,753 ; sosyalleşme faktörünün güvenilirliği 0,692; haber takibi faktörünün güvenilirliği 0,710; ölçeğin güvenilirliği 0,872 ile yüksek düzeydedir.

\footnotetext{
1 “B3-Bankacıllk ya da finansla ilgili web sitelerini ziyaret ederim."; “B9-Blog sayfalarını okurum.”; “S3-Tartışma gruplarımı ziyaret ederim."; “B8-Dosya indiririm. (müzik, yazılım, video gibi...)”; “S4-Sanal toplulukları ziyaret ederim."; "B6-İş bulma ya da kariyer sitelerini ziyaret ederim."; "B7-Kişisel web sayfamı geliştiririm.."; "S1-Online oyun oynarım."
} 
C. Ş. Eyel - A. Tutcu 12/4 (2020) 3596-3612

Tablo 2. Sanal Kaytarma Ölçeği İçin Geçerlilik ve Güvenilirlik Analizi Bulguları

\begin{tabular}{|c|c|c|c|c|c|c|c|}
\hline Kod & İfade & $\begin{array}{l}\text { Arama } \\
\text { Yapma }\end{array}$ & $\begin{array}{c}\text { Bireysel } \\
\text { İşler } \\
\end{array}$ & Sosyalleşme & $\begin{array}{l}\text { Haber } \\
\text { Takibi }\end{array}$ & $\begin{array}{c}\text { Güveni } \\
\text { lirlik }\end{array}$ & Ölçek \\
\hline A2 & $\begin{array}{l}\text { A2-İşle alakalı olmayan } \\
\text { kavramlar hakkında bilgi } \\
\text { toplamaya çalışırım. }\end{array}$ & 0,858 & & & & \multirow{4}{*}{0,817} & \multirow{15}{*}{0,872} \\
\hline $\mathrm{A} 1$ & $\begin{array}{l}\text { A1-İşle alakası olmayan ilginç } \\
\text { (resim, video, özlü sözler vb.) } \\
\text { siteleri arama motorlarında } \\
\text { ararım. }\end{array}$ & 0,772 & & & & & \\
\hline A4 & $\begin{array}{l}\text { A4-Arama motorlarında ilginç } \\
\text { konuların peşine düşerim. }\end{array}$ & 0,681 & & & & & \\
\hline A3 & $\begin{array}{l}\text { A3-Kişilerin biyografik } \\
\text { bilgilerini arama motorlarında } \\
\text { aratırım. }\end{array}$ & 0,629 & & & & & \\
\hline B2 & $\begin{array}{l}\text { B2-Tatil/Seyahat sitelerine } \\
\text { girerim. }\end{array}$ & & 0,837 & & & \multirow{4}{*}{0,753} & \\
\hline B5 & $\begin{array}{l}\text { B5-Seyahat/tatil için yer } \\
\text { ayırtırım. }\end{array}$ & & 0,753 & & & & \\
\hline B4 & \begin{tabular}{|lrr}
$\begin{array}{l}\text { B4-Açık } \\
\text { ziyaret }\end{array}$ & artırma & sitelerini \\
gittigidiyor.com) & (Ör: \\
\end{tabular} & & 0,600 & & & & \\
\hline B1 & $\begin{array}{ll}\begin{array}{l}\text { B1-Çevrimiçi } \\
\text { sitelerine girerim. }\end{array} & \text { alışveriş } \\
\end{array}$ & & 0,585 & & & & \\
\hline S5 & $\begin{array}{l}\text { S5-Anlık mesajlar alırım ve } \\
\text { gönderirim. }\end{array}$ & & & 0,741 & & \multirow{3}{*}{0,692} & \\
\hline S2 & \begin{tabular}{|l|}
$\begin{array}{l}\text { S2-E-postalarımı kontrol } \\
\text { ederim. }\end{array}$ \\
\end{tabular} & & & 0,718 & & & \\
\hline S6 & $\begin{array}{l}\text { S6-Sosyal ağları ziyaret ederim } \\
\text { (Facebook, Twitter, haber } \\
\text { grupları, chat odaları, } \\
\text { çevrimiçi oyunlar vb.) }\end{array}$ & & & 0,581 & & & \\
\hline H3 & $\begin{array}{l}\text { H3-Spor içerikli web sitelerini } \\
\text { ziyaret ederim. }\end{array}$ & & & & 0,829 & \multirow{4}{*}{0,71} & \\
\hline $\mathrm{H} 2$ & $\begin{array}{|ll|}\begin{array}{l}\text { H2-Haber sitelerini ziyaret } \\
\text { ederim. }\end{array} & \\
\end{array}$ & & & & 0,646 & & \\
\hline $\mathrm{H} 1$ & $\begin{array}{l}\text { H1-Haber } \text { gruplarını ve } \\
\text { duyuru panolarını ziyaret } \\
\text { ederim. }\end{array}$ & & & & 0,586 & & \\
\hline $\mathrm{H} 4$ & $\begin{array}{l}\text { H4-Hava durumunu kontrol } \\
\text { ederim. }\end{array}$ & & & & 0,530 & & \\
\hline & Açıklanan Varyans & $17,91 \%$ & $14,76 \%$ & $14,54 \%$ & $14,12 \%$ & \multirow{2}{*}{\multicolumn{2}{|c|}{ Toplam $\% 61,332$}} \\
\hline & KMO: 0 & $361 ; \mathrm{Ki}-\mathrm{Ka}$ & 2220,840 & ; sd: 105; Siq & 000 & & \\
\hline
\end{tabular}

${ }^{*}$ A: Arama Yapma; B: Bireysel İşler, S: Sosyalleşme; H: Haber Takibi

Gerçekleştirilen faktör ve güvenilirlik analizleri neticesinde ortaya çıan faktörlere ilişkin tanımlayıcı bulgular Tablo 3'te sunulmuştur. Buna göre iş doyumunun ortalaması $X=3,6746$ ile yüksek düzeyde, arama yapmanın ortalaması $X=2,9776$ ile ortalamanın altında, bireysel işlerin ortalaması $X=2,6556$ ile düşük düzeyde, sosyalleşmenin ortalaması $X=4,0040$ ile yüksek düzeyde, haber takibinin ortalaması $X=3,2906$ ile ortalamanın üzerindedir. 
C. Ş. Eyel - A. Tutcu 12/4 (2020) 3596-3612

Tablo 3. Faktörlere İlişkin Tanımlayıcı Bulgular

\begin{tabular}{|c|c|c|c|c|c|c|c|c|c|}
\hline Değişken & Sayı & Min. & Maks. & Ort. & SS & Çarpıklık & $\begin{array}{c}\text { Çarpıklık } \\
\text { SH }\end{array}$ & Basıklık & Basıklık SH \\
\hline İş Doyumu & 413 & 1,00 & 5,00 & 3,6746 & 0,97346 & $-0,559$ & 0,120 & $-0,378$ & 0,240 \\
\hline $\begin{array}{c}\text { Arama } \\
\text { Yapma }\end{array}$ & 413 & 1,00 & 5,00 & 2,9776 & 1,04319 & $-0,088$ & 0,120 & $-0,846$ & 0,240 \\
\hline $\begin{array}{c}\text { Bireysel } \\
\text { İşler }\end{array}$ & 413 & 1,00 & 5,00 & 2,6556 & 0,99048 & 0,237 & 0,120 & $-0,799$ & 0,240 \\
\hline \begin{tabular}{c} 
Sosyalleşme \\
\hline $\begin{array}{c}\text { Haber } \\
\text { Takibi }\end{array}$
\end{tabular} & 413 & 1,00 & 5,00 & 4,0040 & 0,94466 & $-0,959$ & 0,120 & 0,282 & 0,240 \\
\hline
\end{tabular}

\subsection{Araştırma Modeli ve Hipotezler}

Ölçekler üzerinde gerçekleştirilen faktör ve güvenilirlik analizlerinin ardından araştırma modeli meydana getirilmiştir. Araştırma modeli Şekil 1'de gösterilmiş olup, bu model doğrultusunda şu ana ve alt hipotezler oluşturulmuştur.

H1: İş doyumu, sanal kaytarma davranışını etkilemektedir.

H1a: İş doyumu, arama yapmayı etkilemektedir.

H1b: İş doyumu, bireysel işleri etkilemektedir.

H1c: İş doyumu, sosyalleşmeyi etkilemektedir.

H1d: İş doyumu, haber takibini etkilemektedir.

H2: İş doyumu, demografik özelliklere göre farklılaşmaktadır.

H2a: İş doyumu, cinsiyete göre farklılaşmaktadır.

H2b: İş doyumu, medeni duruma göre farklılaşmaktadır.

H2c: İş doyumu, yaş grubuna göre farklılaşmaktadır.

H2d: İş doyumu, eğitim düzeyine göre farklılaşmaktadır.

H2e: İş doyumu, aylık gelir durumuna göre farklılaşmaktadır.

H3: Arama yapma, demografik özelliklere göre farklılaşmaktadır.

H3a: Arama yapma, cinsiyete göre farklılaşmaktadır.

H3b: Arama yapma, medeni duruma göre farklılaşmaktadır.

H3c: Arama yapma, yaş grubuna göre farklılaşmaktadır.

H3d: Arama yapma, eğitim düzeyine göre farklılaşmaktadır.

H3e: Arama yapma, aylık gelir durumuna göre farklılaşmaktadır.

H4: Bireysel işler, demografik özelliklere göre farklılaşmaktadır.

H4a: Bireysel işler, cinsiyete göre farklılaşmaktadır.

H4b: Bireysel işler, medeni duruma göre farklılaşmaktadır.

H4c: Bireysel işler, yaş grubuna göre farklılaşmaktadır.

H4d: Bireysel işler, eğitim düzeyine göre farklılaşmaktadır.

H4e: Bireysel işler, aylık gelir durumuna göre farklılaşmaktadır.

H5: Sosyalleşme, demografik özelliklere göre farklılaşmaktadır.

H4a: Sosyalleşme, cinsiyete göre farklılaşmaktadır. 
H4b: Sosyalleşme, medeni duruma göre farklılaşmaktadır.

H4c: Sosyalleşme, yaş grubuna göre farklılaşmaktadır.

H4d: Sosyalleşme, eğitim düzeyine göre farklılaşmaktadır.

H4e: Sosyalleşme, aylık gelir durumuna göre farklılaşmaktadır.

H6: Haber takibi, demografik özelliklere göre farklılaşmaktadır.

H4a: Haber takibi, cinsiyete göre farklılaşmaktadır.

H4b: Haber takibi, medeni duruma göre farklılaşmaktadır.

H4c: Haber takibi, yaş grubuna göre farklılaşmaktadır.

H4d: Haber takibi, eğitim düzeyine göre farklılaşmaktadır.

H4e: Haber takibi, aylık gelir durumuna göre farklılaşmaktadır.

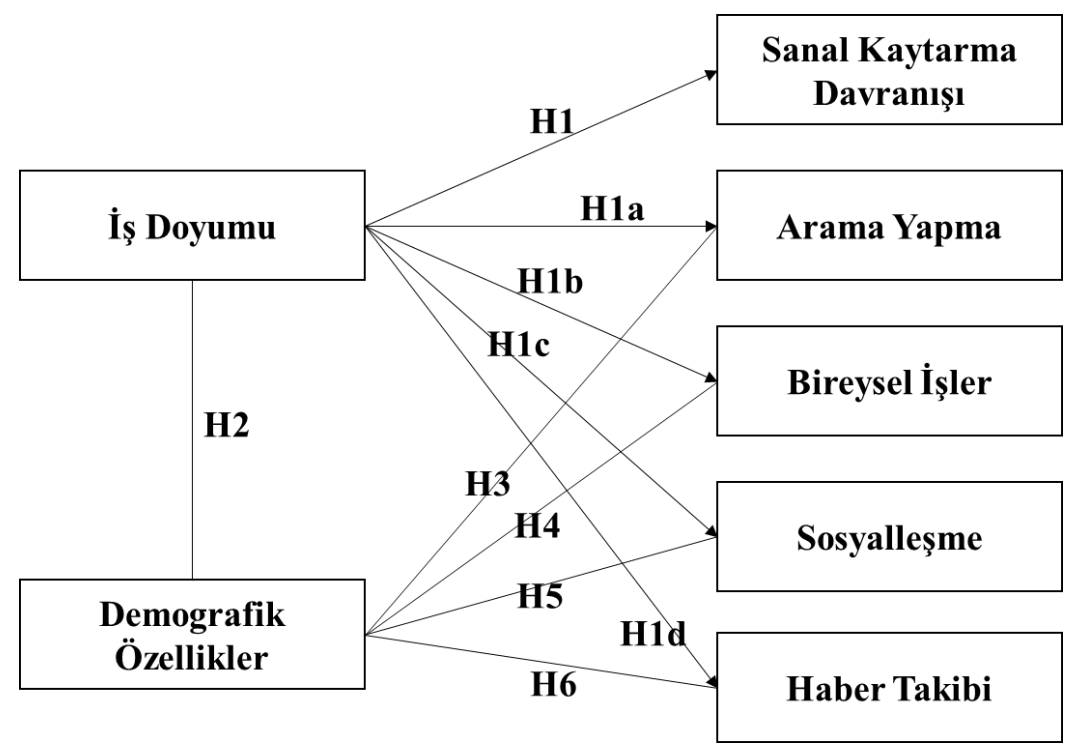

Şekil 1. Araştırma Modeli

\subsection{Araştırmanın Sınırlılıkları}

$\mathrm{Bu}$ çalışmanın çeşitli sınırlılıkları bulunmaktadır. Öncelikle konu bakımından çalışma iş doyumu ve sanal kaytarma davranışı ile sınırlıdır. Kapsam bakımından çalışma, Gaziantep ilinde özel sektörde çalışanlar ile sınırlı durumdadır. Bu doğrultuda araştırmanın bulguları, 413 özel sektör çalışanının anket formuna vermiş oldukları yanıtlarla sınırlıdır. Çalışmada ayrıca zaman sınırlılı̆̆ı mevcuttur. Zira anket uygulaması 21 Nisan 2019 ile 17 Temmuz 2019 tarihleri arasında gerçekleştirilmiştir.

\section{BULGULAR}

Bu bölümde, araştırmaya katılmış olan kişilerin demografik özelliklerine ilişkin bulgular ve belirlenmiş olan hipotezlerin test edilmesi neticesinde ortaya çıkan bulgulara yer verilmiştir.

Araştırmaya katılan 413 kişinin cinsiyete göre 239'u (\%57,9) kadın, 174'ü $(\% 42,1)$ erkektir. Medeni durum bakımından 195'i (\%47,2) bekâr, 218'i (\%52,8) evlidir. Yaş grubu açısından 54'ü (\%13,1) 18-25 yaş grubunda, 154 'ü (\%37,3) 26-34 yaş grubunda, 101'i (\%24,5) 35-44 yaş grubunda, 74'ü (\%17,9) 45-54 yaş grubunda, 30'u $(\% 7,2) 55$ ve üzeri yaş grubundadır. Eğitim düzeyine göre 31 kişi $(\% 7,5)$ lise mezunu, 168 kişi $(\% 40,7)$ lisans mezunu, 214 kişi $(\% 51,8)$ lisansüstü mezunudur. Aylık gelir durumu bakımından 54 kişi (\%13,1) 2.500 TL'nin altında, 134 kişi (\%32,4) 2.500 TL - 5.000 TL arasında, 113 kişi (\%27,4) 5.001 TL - 7.500 TL arasında, 61 kişi (\%14,8) 7.500 TL - 10.000 TL arasında, 51 kişi (\%12,3) 10.000 TL'den fazla aylık gelire sahiptir.

"H1: İş doyumu, sanal kaytarma davranışını etkilemektedir." hipotezini test etmek üzere "H1a: İş doyumu, arama yapmayı etkilemektedir."; "H1b: İş doyumu, bireysel işleri etkilemektedir."; "H1c: İş doyumu, sosyalleşmeyi etkilemektedir." ve "H1d: İs doyumu, haber takibini etkilemektedir." alt hipotezleri oluşturulmuş ve her bir alt 
hipotezi test etmek üzere basit doğrusal regresyon analizleri gerçekleştirilmiştir. Analiz bulguları toplu şekilde Tablo $4^{\prime}$ te sunulmuştur.

"H1a: İş doyumu, arama yapmayı etkilemektedir." hipotezini test etmek üzere yapılan basit doğrusal regresyon analizi neticesinde $\mathrm{F}(0,394)$ ve $\mathrm{p}(0,150>0,05)$ değerlerine göre modelin anlamlı olmadığı görülmektedir. Bu bulguya göre, iş doyumunun arama yapma üzerinde anlamlı bir etkisi bulunmamaktadır $(\mathrm{p}=0,150)$. Bu doğrultuda, "H1a: İ̧̧ doyumu, arama yapmayı etkilemektedir." hipotezi reddedilmiştir.

"H1b: İş doyumu, bireysel işleri etkilemektedir." hipotezini test etmek üzere yapılan basit doğrusal regresyon analizi neticesinde $\mathrm{F}(0,394)$ ve $\mathrm{p}(0,531>0,05)$ değerlerine göre modelin anlamlı olmadığ görülmektedir. Bu bulguya göre, iş doyumunun bireysel işler üzerinde anlamlı bir etkisi bulunmamaktadır $(\mathrm{p}=0,531)$. Bu doğrultuda, "H1b: İs doyumu, bireysel işleri etkilemektedir." hipotezi reddedilmiştir.

"H1c: İş doyumu, sosyalleşmeyi etkilemektedir." hipotezini test etmek üzere yapılan basit doğrusal regresyon analizi neticesinde $\mathrm{F}(0,897)$ ve $\mathrm{p}(0,344>0,05)$ değerlerine göre modelin anlamlı olmadığı görülmektedir. Bu bulguya göre, iş doyumunun sosyalleşme üzerinde anlamlı bir etkisi bulunmamaktadır $(\mathrm{p}=0,344)$. Bu doğrultuda, "H1c: İ̧̧ doyumu, sosyalleşmeyi etkilemektedir." hipotezi reddedilmiştir.

"H1d: Isş doyumu, haber takibini etkilemektedir." hipotezini test etmek üzere yapılan basit doğrusal regresyon analizi neticesinde $\mathrm{F}(0,175)$ ve $\mathrm{p}(0,676>0,05)$ değerlerine göre modelin anlamlı olmadığ görülmektedir. Bu bulguya göre, iş doyumunun haber takibi üzerinde anlamlı bir etkisi bulunmamaktadır $(\mathrm{p}=0,676)$. Bu doğrultuda, "H1d: İş doyumu, haber takibini etkilemektedir." hipotezi reddedilmiştir.

$\mathrm{H} 1 \mathrm{a}, \mathrm{H} 1 \mathrm{~b}, \mathrm{H} 1 \mathrm{c}$ ve H1d için gerçekleştirilen hipotez testleri neticesinde "H1: Iş̧ doyumu, sanal kaytarma davranışını etkilemektedir." ana hipotezi reddedilmiştir.

Tablo 4. Basit Doğrusal Regresyon Analizi Bulguları

\begin{tabular}{|c|c|c|c|c|c|c|}
\hline $\begin{array}{c}\text { Bağımlı Değişken: Arama } \\
\text { Yapma }\end{array}$ & Beta & t-değeri & Sig. & $\mathbf{R}^{2}$ & F-değeri & Model Sig. \\
\hline Sabit & & 16,253 & 0,000 & \multirow{2}{*}{$0,50 \%$} & \multirow{2}{*}{2,083} & \multirow{2}{*}{0,150} \\
\hline İş Doyumu & $-0,071$ & $-1,443$ & 0,150 & & & \\
\hline $\begin{array}{c}\text { Bağımlı Değissken: Bireysel } \\
\text { İşler }\end{array}$ & Beta & t-değeri & Sig. & $\mathbf{R}^{2}$ & F-değeri & Model Sig. \\
\hline Sabit & & 14,534 & 0,000 & \multirow{2}{*}{$0,10 \%$} & \multirow{2}{*}{0,394} & \multirow{2}{*}{0,531} \\
\hline İş Doyumu & $-0,031$ & $-0,628$ & 0,531 & & & \\
\hline $\begin{array}{l}\text { Bağımlı Değişken: } \\
\text { Sosyalleşme }\end{array}$ & Beta & t-değeri & Sig. & $\mathbf{R}^{2}$ & F-değeri & Model Sig. \\
\hline Sabit & & 21,116 & 0,000 & \multirow{2}{*}{$0,20 \%$} & \multirow{2}{*}{0,897} & \multirow{2}{*}{0,344} \\
\hline İş Doyumu & 0,047 & 0,947 & 0,344 & & & \\
\hline $\begin{array}{c}\text { Bağımlı Değişken: Haber } \\
\text { Takibi }\end{array}$ & Beta & t-değeri & Sig. & $\mathbf{R}^{2}$ & F-değeri & Model Sig. \\
\hline Sabit & & 18,748 & 0,000 & \multirow{2}{*}{$0,00 \%$} & \multirow{2}{*}{0,175} & \multirow{2}{*}{0,676} \\
\hline İş Doyumu & $-0,021$ & $-0,418$ & 0,676 & & & \\
\hline
\end{tabular}

Katılımcıların iş doyumu, arama yapma, bireysel işler, sosyalleşme ve haber takibi için vermiş oldukları yanıtların cinsiyete göre farklılaşıp farklılaşmadığını test etmek üzere Bağımsız Örneklem T Testi gerçekleştirilmiştir. Analiz bulguları Tablo 5'te yansıtılmıştır. Tabloda görüldüğü üzere, yalnızca haber takibinde anlamlı farklılık tespit edilmiştir $(\mathrm{t}=-4,480 ; \mathrm{p}=0,000)$. Katılımcıların verdikleri yanıtların ortalamalarına bakıldığında, erkeklerin $(X=3,5259)$ kadınlara $(X=3,1192)$ kıyasla iş yerinde daha çok haber takibi yaptıkları tespit edilmiştir. Bu doğrultuda, "H6a: Haber takibi, cinsiyete göre farklılaşmaktadır." hipotezi kabul edilmiş; "H2a: İş doyumu, cinsiyete göre farklılaşmaktadır."; "H3a: Arama yapma, cinsiyete göre farklılaşmaktadır."; "H4a: Bireysel işler, cinsiyete göre farklılaşmaktadır." ve "H5a: Sosyalleşme, cinsiyete göre farklılaşmaktadır." hipotezleri ise reddedilmiştir. 
C. Ş. Eyel - A. Tutcu 12/4 (2020) 3596-3612

Tablo 5. Cinsiyete Göre Bağımsız Örneklem T Testi Bulguları

\begin{tabular}{|c|c|c|c|c|c|c|c|}
\hline Değişken & Cinsiyet & Say1 & Ort. & SS & t-değeri & sd & Sig. \\
\hline \multirow{2}{*}{ İş Doyumu } & Kadın & 239 & 3,6946 & 0,97873 & \multirow{2}{*}{0,489} & \multirow{2}{*}{411} & \multirow{2}{*}{0,625} \\
\hline & Erkek & 174 & 3,6471 & 0,96832 & & & \\
\hline \multirow{2}{*}{ Arama } & Kadın & 239 & 2,9027 & 0,97592 & \multirow{2}{*}{$-1,714$} & \multirow{2}{*}{411} & \multirow{2}{*}{0,095} \\
\hline & Erkek & 174 & 3,0805 & 1,12383 & & & \\
\hline \multirow{2}{*}{ Bireysel İşler } & Kadın & 239 & 2,6684 & 0,96233 & \multirow{2}{*}{0,308} & \multirow{2}{*}{411} & \multirow{2}{*}{0,758} \\
\hline & Erkek & 174 & 2,6379 & 1,03043 & & & \\
\hline \multirow{2}{*}{ Sosyalleşme } & Kadın & 239 & 3,9791 & 0,96097 & \multirow{2}{*}{$-0,629$} & \multirow{2}{*}{411} & \multirow{2}{*}{0,530} \\
\hline & Erkek & 174 & 4,0383 & 0,92343 & & & \\
\hline \multirow{2}{*}{ Haber Takibi } & Kadın & 239 & 3,1192 & 0,84510 & \multirow{2}{*}{$-4,480$} & \multirow{2}{*}{411} & \multirow{2}{*}{0,000} \\
\hline & Erkek & 174 & 3,5259 & 0,99386 & & & \\
\hline
\end{tabular}

Katılımcıların iş doyumu, arama yapma, bireysel işler, sosyalleşme ve haber takibi için vermiş oldukları yanıtların medeni duruma göre farklılaşıp farklılaşmadığını test etmek üzere Bağımsız Örneklem T Testi gerçekleştirilmiştir. Analiz bulguları Tablo 6'da yansıtılmıştır. Tabloda görüldüğü üzere, yalnızca arama yapmada anlamlı farklılık tespit edilmiştir $(\mathrm{t}=2,170 ; \mathrm{p}=0,030)$. Katılımcıların verdikleri yanıtların ortalamalarına bakıldığında, bekârların $(X=3,0949)$ evlilere $(X=2,8727)$ kıyasla iş yerinde internette daha çok arama yaptıkları tespit edilmiştir. Bu doğrultuda, "H3b: Arama yapma, medeni duruma göre farklllaşmaktadır." hipotezi kabul edilmiş; "H2b: İş doyumu, medeni duruma göre farklılaşmaktadır."; "H4b: Bireysel işler, medeni duruma göre farklılaşmaktadır."; "H5b: Sosyalleşme, medeni duruma göre farklılaşmaktadır." ve "H6b: Haber takibi, medeni duruma göre farklılaşmaktadır." ve hipotezleri ise reddedilmiştir.

Tablo 6. Medeni Duruma Göre Bağımsız Örneklem T Testi Bulguları

\begin{tabular}{|c|c|c|c|c|c|c|c|}
\hline Değişken & $\begin{array}{l}\text { Medeni } \\
\text { Durum }\end{array}$ & Sayı & Ort. & SS & t-değeri & sd & Sig. \\
\hline \multirow{2}{*}{ İş Doyumu } & Bekâr & 195 & 3,5969 & 0,95280 & \multirow{2}{*}{$-1,536$} & \multirow{2}{*}{411} & \multirow{2}{*}{0,125} \\
\hline & Evli & 218 & 3,7440 & 0,98859 & & & \\
\hline \multirow{2}{*}{ Arama } & Bekâr & 195 & 3,0949 & 0,97915 & \multirow{2}{*}{2,170} & \multirow{2}{*}{411} & \multirow{2}{*}{0,030} \\
\hline & Evli & 218 & 2,8727 & 1,08886 & & & \\
\hline \multirow{2}{*}{ Bireysel İşler } & Bekâr & 195 & 2,7385 & 0,92756 & \multirow{2}{*}{1,612} & \multirow{2}{*}{411} & \multirow{2}{*}{0,108} \\
\hline & Evli & 218 & 2,5814 & 1,04008 & & & \\
\hline \multirow{2}{*}{ Sosyalleşme } & Bekâr & 195 & 4,0991 & 0,93817 & \multirow{2}{*}{1,942} & \multirow{2}{*}{411} & \multirow{2}{*}{0,053} \\
\hline & Evli & 218 & 3,9190 & 0,94447 & & & \\
\hline \multirow{2}{*}{ Haber Takibi } & Bekâr & 195 & 3,2910 & 1,00044 & \multirow{2}{*}{0,010} & \multirow{2}{*}{411} & \multirow{2}{*}{0,992} \\
\hline & Evli & 218 & 3,2901 & 0,86758 & & & \\
\hline
\end{tabular}

Katılımcıların iş doyumu, arama yapma, bireysel işler, sosyalleşme ve haber takibi için vermiş oldukları yanıtların yaş grubuna göre farklılaşıp farklılaşmadığını test etmek üzere ANOVA Testi gerçekleştirilmiştir. Analiz bulguları Tablo 7'de yansıtılmıştır. Tabloda görüldüğü üzere, iş doyumunda $(\mathrm{F}=4,604 ; \mathrm{p}=0,001)$ ve arama yapmada $(\mathrm{F}=3,238 ; \mathrm{p}=0,012)$ anlamlı farklılık tespit edilmiştir. Bu farklılıkların nereden kaynaklandığını tespit etmek için öncelikle Levene homojenlik testi yapılmış; iş doyumunda (Levene $=1,618 ; p=0,169$ ) ve arama yapmada (Levene $=0,208 ; \mathrm{p}=0,934$ ) şeklinde tespit edildiğinden, bu doğrultuda her iki faktör için de varyansların homojen olduğu saptanmış ve Tukey post hoc testleri gerçekleştirilmiştir. Tukey post hoc testleri neticesinde, 45-54 yaş grubundakilerin $(X=4,0270), 18-25$ yaş grubundakilere $(X=3,3815), 26-34$ yaş grubundakilere $(X=3,6091), 35-44$ yaş grubundakilere $(X=3,6000)$ ve 45 ve üzeri yaş grubundakilere $(X=3,9200)$ kıyasla daha fazla iş doyumuna sahip oldukları bulgusuna erişilmiştir. Ayrıca 18-25 yaş grubundakilerin $(X=3,3333), 45-54$ yaş grubundakilere $(X=2,7095)$ kıyasla daha fazla arama yaptıkları bulgusu elde edilmiştir. Bu doğrultuda, "H2c: İ̧̧ doyumu, yaş grubuna göre farklılaşmaktadır." ve "H3c: Arama yapma, yaş grubuna göre farkhlaşmaktadır." hipotezleri kabul edilmiş; "H4c: Bireysel işler, yaş grubuna göre farklılaşmaktadır."; "H5c: 
C. Ş. Eyel - A. Tutcu 12/4 (2020) 3596-3612

Sosyalleşme, yaş grubuna göre farkllaş̧maktadır." ve "H6c: Haber takibi, yaş grubuna göre farklılaşmaktadır." ve hipotezleri ise reddedilmiştir.

Tablo 7. Yaş Grubuna Göre ANOVA Testi Bulguları

\begin{tabular}{|c|c|c|c|c|c|c|c|}
\hline Değişken & Yaş Grubu & Sayı & Ort. & SS & F-değeri & Sig. & Anlamlı Fark \\
\hline \multirow{5}{*}{ İş Doyumu } & $18-25$ & 54 & 3,3815 & 0,80776 & \multirow{5}{*}{4,604} & \multirow{5}{*}{0,001} & \multirow{5}{*}{$4-1,4-2,4-3,4-5$} \\
\hline & $26-34$ & 154 & 3,6091 & 1,00387 & & & \\
\hline & $35-44$ & 101 & 3,6000 & 1,02059 & & & \\
\hline & $45-54$ & 74 & 4,0270 & 0,88167 & & & \\
\hline & 55 ve üzeri & 30 & 3,9200 & 0,90759 & & & \\
\hline \multirow{5}{*}{ Arama } & $18-25$ & 54 & 3,3333 & 1,01638 & \multirow{5}{*}{3,238} & \multirow{5}{*}{0,012} & \multirow{5}{*}{$1-4$} \\
\hline & $26-34$ & 154 & 2,9205 & 1,00396 & & & \\
\hline & $35-44$ & 101 & 3,0173 & 1,07195 & & & \\
\hline & $45-54$ & 74 & 2,7095 & 1,05095 & & & \\
\hline & 55 ve üzeri & 30 & 3,1583 & 1,01812 & & & \\
\hline \multirow{5}{*}{ Bireysel } & $18-25$ & 54 & 2,8519 & 0,90663 & \multirow{5}{*}{1,785} & \multirow{5}{*}{0,131} & \\
\hline & $26-34$ & 154 & 2,7451 & 1,02679 & & & \\
\hline & $35-44$ & 101 & 2,5965 & 1,05177 & & & \\
\hline & $45-54$ & 74 & 2,4865 & 0,90460 & & & \\
\hline & 55 ve üzeri & 30 & 2,4583 & 0,87119 & & & \\
\hline \multirow{5}{*}{ Sosyalleşme } & $18-25$ & 54 & 4,1296 & 0,97434 & \multirow{5}{*}{0,320} & \multirow{5}{*}{0,865} & \\
\hline & $26-34$ & 154 & 3,9978 & 0,88684 & & & \\
\hline & $35-44$ & 101 & 3,9505 & 1,05871 & & & \\
\hline & $45-54$ & 74 & 4,0000 & 0,91661 & & & \\
\hline & 55 ve üzeri & 30 & 4,0000 & 0,87974 & & & \\
\hline \multirow{5}{*}{$\begin{array}{l}\text { Haber } \\
\text { Takibi }\end{array}$} & $18-25$ & 54 & 3,3380 & 0,96783 & \multirow{5}{*}{0,057} & \multirow{5}{*}{0,994} & \\
\hline & $26-34$ & 154 & 3,2792 & 0,97809 & & & \\
\hline & $35-44$ & 101 & 3,2871 & 0,92357 & & & \\
\hline & $45-54$ & 74 & 3,3007 & 0,88749 & & & \\
\hline & 55 ve üzeri & 30 & 3,2500 & 0,79871 & & & \\
\hline
\end{tabular}

Katılımcıların iş doyumu, arama yapma, bireysel işler, sosyalleşme ve haber takibi için vermiş oldukları yanıtların eğitim düzeyine göre farklılaşıp farklılaşmadı̆̆ını test etmek üzere ANOVA Testi gerçekleştirilmiştir. Analiz bulguları Tablo 8'de yansıtılmıştır. Tabloda görüldüğü üzere, arama yapmada $(\mathrm{F}=13,850 ; \mathrm{p}=0,000)$, bireysel işlerde $(\mathrm{F}=12,764 ; \mathrm{p}=0,000)$, sosyalleşmede $(\mathrm{F}=11,294 ; \mathrm{p}=0,000)$ ve haber takibinde $(\mathrm{F}=7,395 ; \mathrm{p}=0,001)$ anlamlı farklılıklar tespit edilmiştir. Bu farklılıkların nereden kaynaklandığını tespit etmek için öncelikle Levene homojenlik testi yapılmış ve arama yapma (Levene $=0,713$; $p=0,491$ ), bireysel işler (Levene $=0,840 ; p=0,433$ ), sosyalleşme (Levene $=1,752 ; p=0,175$ ) ile haber takibi (Levene $=0,380 ; p=0,684$ ) için varyansların homojen olduğu saptandığından, Tukey post hoc testleri gerçekleştirilmiş. Tukey post hoc testleri neticesinde şu bulgulara erişilmiştir:

- Arama yapma için lisans mezunları $(X=3,1458)$ ve lisansüstü mezunları $(X=2,9720)$; lise mezunlarına $(X=2,1048)$ kıyasla daha yüksek yanıtlar vermişlerdir.

- Bireysel işler için lisans mezunları $(X=2,7768)$ ve lisansüstü mezunları $(X=2,6799)$; lise mezunlarına $(X=1,8306)$ kıyasla daha yüksek yanıtlar vermişlerdir.

- Sosyalleşme için lisans mezunları $(X=4,0694)$ ile lisansüstü mezunları $(X=4,0623)$; lise mezunlarına $(X=3,2473)$ kıyasla daha yüksek yanıtlar vermişlerdir.

- Haber takibi için lisans mezunları $(X=3,4836)$; lise mezunlarına $(X=2,9274)$ ve lisansüstü mezunlarına $(X=3,1916)$ kıyasla daha yüksek yanıtlar vermişlerdir. 
C. Ş. Eyel - A. Tutcu 12/4 (2020) 3596-3612

Bu doğrultuda; "H3d: Arama yapma, eğitim düzeyine göre farklılaşmaktadır."; "H4d: Bireysel işler, eğitim düzeyine göre farklılaşmaktadır."; "H5d: Sosyalleşme, eğitim düzeyine göre farklllaşmaktadır." ve "H6d: Haber takibi, eğitim düzeyine göre farklılaşmaktadır." hipotezleri kabul edilmiş; "H2d: İş doyumu, eğitim düzeyine göre farklılaşmaktadır." hipotezi ise reddedilmiştir.

Tablo 8. Eğitim Düzeyine Göre ANOVA Testi Bulguları

\begin{tabular}{|c|c|c|c|c|c|c|c|}
\hline Değişken & Eğitim Düzeyi & Sayı & Ort. & SS & F-değeri & Sig. & Anlamlı Fark \\
\hline \multirow{3}{*}{ İş Doyumu } & Lise & 31 & 3,5161 & 1,12163 & \multirow{3}{*}{0,775} & \multirow{3}{*}{0,462} & \\
\hline & Lisans & 168 & 3,6417 & 0,91373 & & & \\
\hline & Lisansüstü & 214 & 3,7234 & 0,99714 & & & \\
\hline \multirow{3}{*}{ Arama } & Lise & 31 & 2,1048 & 0,90548 & \multirow{3}{*}{13,850} & \multirow{3}{*}{0,000} & \multirow{3}{*}{$2-1,3-1$} \\
\hline & Lisans & 168 & 3,1458 & 0,98165 & & & \\
\hline & Lisansüstü & 214 & 2,9720 & 1,04916 & & & \\
\hline \multirow{3}{*}{ Bireysel } & Lise & 31 & 1,8306 & 0,83762 & \multirow{3}{*}{12,764} & \multirow{3}{*}{0,000} & \multirow{3}{*}{$2-1,3-1$} \\
\hline & Lisans & 168 & 2,7768 & 0,98227 & & & \\
\hline & Lisansüstü & 214 & 2,6799 & 0,96493 & & & \\
\hline \multirow{3}{*}{ Sosyalleşme } & Lise & 31 & 3,2473 & 1,10543 & \multirow{3}{*}{11,294} & \multirow{3}{*}{0,000} & \multirow{3}{*}{$2-1,3-1$} \\
\hline & Lisans & 168 & 4,0694 & 0,89566 & & & \\
\hline & Lisansüstü & 214 & 4,0623 & 0,91373 & & & \\
\hline \multirow{3}{*}{ Haber Takibi } & Lise & 31 & 2,9274 & 0,91786 & \multirow{3}{*}{7,395} & \multirow{3}{*}{0,001} & \multirow{3}{*}{$2-1,2-3$} \\
\hline & Lisans & 168 & 3,4836 & 0,88869 & & & \\
\hline & Lisansüstü & 214 & 3,1916 & 0,93922 & & & \\
\hline
\end{tabular}

Katılımcıların iş doyumu, arama yapma, bireysel işler, sosyalleşme ve haber takibi için vermiş oldukları yanıtların aylık gelir durumuna göre farklılaşıp farklılaşmadığını test etmek üzere ANOVA Testi gerçekleştirilmiştir. Analiz bulguları Tablo 9'da yansıtılmıştır. Tabloda görüldügü üzere, yalnızca iş doyumunda $(\mathrm{F}=14,851 ; \mathrm{p}=0,000)$ anlamlı farklılık tespit edilmiştir. Bu farklılığın nereden kaynaklandığını tespit etmek için öncelikle Levene homojenlik testi yapılmış ve iş doyumu (Levene=1,522; $\mathrm{p}=0,195)$ için varyansın homojen olduğu saptandığından, Tukey post hoc testi gerçekleştirilmiştir. Tukey post hoc testi neticesinde; iş doyumu için aylık geliri $5.001 \mathrm{TL}-7.500 \mathrm{TL}$ arasında olanlar $(\mathrm{X}=3,9221)$, 7.500 TL -10.000 TL arasında olanlar $(X=4,0361)$ ve $10.000 \mathrm{TL}$ 'nin üzerinde olanlar $(X=4,0118) ; 2.500 \mathrm{TL}$ nin altında olanlara $(X=3,0630)$ ve $2.500 \mathrm{TL}-5.000 \mathrm{TL}$ arasında olanlara $(X=3,4194)$ kıyasla daha yüksek yanıtlar vermişlerdir. $\mathrm{Bu}$ doğrultuda; "H2e: İş doyumu, aylık gelir durumuna göre farklılaşmaktadır." hipotezi kabul edilmiş;; "H3e: Arama yapma, aylık gelir durumuna göre farklılaşmaktadır."; "H4e: Bireysel işler, aylık gelir durumuna göre farklılaşmaktadır."; "H5e: Sosyalleşme, aylık gelir durumuna göre farklllaşmaktadır." ve "H6e: Haber takibi, aylık gelir durumuna göre farklılaşmaktadır." hipotezleri ise reddedilmiştir.

Tablo 9. Aylık Gelir Durumuna Göre ANOVA Testi Bulguları

\begin{tabular}{|c|c|c|c|c|c|c|c|}
\hline Değişken & Aylık Gelir Durumu & Sayı & Ort. & SS & F-değeri & Sig. & Anlamlı Fark \\
\hline \multirow{5}{*}{ İş Doyumu } & 2.500 TL'nin altında & 54 & 3,0630 & 1,01150 & \multirow{5}{*}{14,851} & \multirow{5}{*}{0,000} & \multirow{5}{*}{$\begin{array}{l}3-1,3-2,4-1 \\
4-2,5-1,5-2\end{array}$} \\
\hline & $2.500 \mathrm{TL}-5.000 \mathrm{TL}$ & 134 & 3,4194 & 0,92350 & & & \\
\hline & $5.001 \mathrm{TL}-7.500 \mathrm{TL}$ & 113 & 3,9221 & 0,90176 & & & \\
\hline & $7.500 \mathrm{TL}-10.000 \mathrm{TL}$ & 61 & 4,0361 & 0,77847 & & & \\
\hline & 10.000 TL üzeri & 51 & 4,0118 & 0,95617 & & & \\
\hline \multirow{4}{*}{ Arama } & 2.500 TL'nin altında & 54 & 3,1111 & 1,16723 & \multirow{4}{*}{1,234} & \multirow{4}{*}{0,296} & \\
\hline & $2.500 \mathrm{TL}-5.000 \mathrm{TL}$ & 134 & 3,0877 & 0,91677 & & & \\
\hline & $5.001 \mathrm{TL}-7.500 \mathrm{TL}$ & 113 & 2,8274 & 1,03568 & & & \\
\hline & 7.500 TL - $10.000 \mathrm{TL}$ & 61 & 2,9385 & 1,17850 & & & \\
\hline
\end{tabular}


C. Ş. Eyel - A. Tutcu 12/4 (2020) 3596-3612

\begin{tabular}{|c|c|c|c|c|c|c|c|}
\hline & 10.000 TL üzeri & 51 & 2,9265 & 1,05391 & & & \\
\hline \multirow{5}{*}{$\begin{array}{c}\text { Bireysel } \\
\text { İşler }\end{array}$} & 2.500 TL'nin altında & 54 & 2,4028 & 1,12583 & \multirow{5}{*}{1,523} & \multirow{5}{*}{0,195} & \\
\hline & $2.500 \mathrm{TL}-5.000 \mathrm{TL}$ & 134 & 2,7164 & 0,97900 & & & \\
\hline & $5.001 \mathrm{TL}-7.500 \mathrm{TL}$ & 113 & 2,6283 & 0,91741 & & & \\
\hline & $7.500 \mathrm{TL}-10.000 \mathrm{TL}$ & 61 & 2,6352 & 1,11764 & & & \\
\hline & 10.000 TL üzeri & 51 & 2,8480 & 0,82927 & & & \\
\hline \multirow{5}{*}{ Sosyalleşme } & 2.500 TL'nin altında & 54 & 3,9074 & 1,15182 & \multirow{5}{*}{1,373} & \multirow{5}{*}{0,242} & \\
\hline & $2.500 \mathrm{TL}-5.000 \mathrm{TL}$ & 134 & 4,0000 & 0,90943 & & & \\
\hline & $5.001 \mathrm{TL}-7.500 \mathrm{TL}$ & 113 & 4,0914 & 0,83124 & & & \\
\hline & $7.500 \mathrm{TL}-10.000 \mathrm{TL}$ & 61 & 4,1257 & 0,92128 & & & \\
\hline & 10.000 TL üzeri & 51 & 3,7778 & 1,04066 & & & \\
\hline \multirow{5}{*}{$\begin{array}{l}\text { Haber } \\
\text { Takibi }\end{array}$} & 2.500 TL'nin altında & 54 & 3,3102 & 0,98806 & \multirow{5}{*}{0,586} & \multirow{5}{*}{0,673} & \\
\hline & $2.500 \mathrm{TL}-5.000 \mathrm{TL}$ & 134 & 3,3563 & 0,93359 & & & \\
\hline & $5.001 \mathrm{TL}-7.500 \mathrm{TL}$ & 113 & 3,2588 & 0,90134 & & & \\
\hline & $7.500 \mathrm{TL}-10.000 \mathrm{TL}$ & 61 & 3,3197 & 0,90730 & & & \\
\hline & 10.000 TL üzeri & 51 & 3,1324 & 0,97385 & & & \\
\hline
\end{tabular}

Gerçekleştirilen farklılık analizleri neticesinde:

- $\mathrm{H} 2 \mathrm{a}, \mathrm{H} 2 \mathrm{~b}$ ile $\mathrm{H} 2 \mathrm{~d}$ reddedildiği ve $\mathrm{H} 2 \mathrm{c}$ ile H2e kabul edildiği için, "H2: İş doyumu, demografik özelliklere göre farklllaşmaktadır." ana hipotezi kısmen kabul edilmiştir.

- H3a ile H3e reddedildiği ve H3b, H3c ile H3d kabul edildiği için, "H3: Arama yapma, demografik özelliklere göre farklılaşmaktadır." ana hipotezi kısmen kabul edilmiştir.

- H4a, H4b, H4c ile H4e reddedildiği ve H4d kabul edildiği için, "H4: Bireysel işler, demografik özelliklere göre farklllaşmaktadır." ana hipotezi kısmen kabul edilmiştir.

- H5a, H5b, H5c ile H5e reddedildiği ve H5d kabul edildiği için, "H5: Sosyalleşme, demografik özelliklere göre farklılaşmaktadır." ana hipotezi kısmen kabul edilmiştir.

- H6b, H6c ile H6e reddedildiği ve H6a ile H6d kabul edildiği için, "H6: Haber takibi, demografik özelliklere göre farklılaşmaktadır." ana hipotezi kısmen kabul edilmiştir.

\section{SONUÇ VE TARTIŞMA}

Bu çalışma çerçevesinde, Gaziantep ilinde özel sektörde çalışanlar üzerinde iş doyumunun sanal kaytarma davranışı üzerindeki etkisi incelenmiştir. Bununla birlikte hem iş doyumu hem de sanal kaytarma davranışı faktörlerine verilen yanıtların demografik özelliklere göre farklılaşma durumu da test edilmiştir.

Araştırma kapsamında elde edilen verilerin SPSS-22 programında kaydedilmesinin ardından hem iş doyumu ölçeği hem de sanal kaytarma ölçeğinin geçerlilikleri için faktör analizleri ve ayrıca güvenilirlik analizleri gerçekleştirilmiştir. İş doyumu için gerçekleştirilen faktör analizi neticesinde, orijinal ölçekle uyumlu bir yapı elde edilmiştir. Bunun yanında iş doyumunun güvenilirliği de oldukça yüksek düzeyde tespit edilmiştir. Sanal kaytarma ölçeği için gerçekleştirilen faktör analizi neticesinde, orijinal ölçekle uyumlu şekilde dört faktör tespit edilmiş, faktörlerin güvenilirlikleri yüksek düzeyde tespit edilmiştir.

Araştırma çerçevesinde iş doyumunun sanal kaytarma davranışı üzerinde etkisi olup olmadığını tespit etmek üzere, basit doğrusal regresyon analizleri gerçekleştirilmiş ve bu doğrultuda iş doyumunun sanal kaytarma faktörleri üzerinde anlamlı bir etkiye sahip olmadığı saptanmıştır. Yılmaz (2018) tarafından yapılan çalışmada da iş doyumu ile sanal kaytarma arasında anlamlı bir ilişkiye rastlanmamıştır. Ancak literatürdeki pek çok çalışmada iş doyumunun sanal kaytarmayı etkilediğine yönelik bulgulara rastlamak mümkündür (Yıldırım, 2018; Çivilidağ, 2017; Çavuşoğlu ve Palamutçuoğlu, 2017; Cook, 2017; Chaudhuri ve Naskar, 2014; Chomal ve Baruah, 2014; Folami vd., 2014; Alias vd., 2013; Robbins ve Judge, 2013; Özler ve Polat, 2012; Vitak vd., 2011; Garrett ve Danziger, 2008; Manrique de Lara vd., 2006; Stanton, 2002). Bu doğrultuda, yapılan çalışmanın neticesinde, literatür bulgularını genel olarak desteklemeyen bir bulgunun elde edilmiş olduğu söylenebilir. Çalışmada bu şekilde bir bulgu elde edilmiş olması, araştırmanın Gaziantep ilinde gerçekleştirilmiş olması ve örneklem olarak seçilmiş olan kitlenin yapısından kaynaklanıyor olabilir. Zira örneklemin vermiş olduğu 
ortalama yanıtlara göre, sosyalleşme faktörü haricindeki diğer faktörlerin ortalamaya yakın olduğu, ayrıca katılımcıların iş doyumu düzeylerinin de yüksek fakat ortalamaya yakın düzeyde olduğu görülmektedir. Literatürde yapılan çalışmalarda genel olarak iş doyumu ile sanal kaytarma davranışı arasında negatif yönlü ilişkiler tespit edilmiş olduğu hususu göz önünde bulundurulduğunda, verilen yanıtların ortalamalarının birbirine yakın olması ile anlamlı ilişkilere rastlanmaması arasında bir bağlantı olduğu yorumu yapılabilir. Ayrıca iş doyumunun arama yapma, bireysel işler, sosyalleşme ve haber takibi faktörleri üzerinde anlamlı bir etkisinin tespit edilememiş olmasının nedeni, artık internet ile sosyal medyanın hem günlük hayatta hem de çalışma yaşamında oldukça önemli bir yer edinmiş olması ve normal bir davranış şeklinde algılanmaya başlanmış olması şeklinde de değerlendirilebilir.

İş doyumunun sanal kaytarma davranışı üzerindeki etkisine ilişkin analizlerin ardından, iş doyumu ile sanal kaytarma davranışı faktörlerine verilmiş olan yanıtların demografik özelliklere göre farklılaşma durumu test edilmiştir. Cinsiyete göre yapılan farklılık analizinde, yalnızca haber takibi faktöründe erkek katılımcılar lehine anlamlı farklılığa rastlanmıştır. Yaşar (2013) tarafından yapılan çalışmada da arama yapmada erkekler lehine anlamlı farklılık tespit edilmiştir. Buna göre, çalışmada elde edilen bu bulgunun literatür bulgularıla paralelliğe sahip olduğu söylenebilir. Nitekim Mastrangelo vd. (2006); Jackson vd. (2001); Vitak vd. (2011); Garrett ve Dangizer (2008); Vitak vd. (2011) tarafından yapılan çalışmalarda erkeklerin daha fazla sanal kaytarma davranışı sergiledikleri belirtilmiştir. Bununla birlikte, Yaşar (2013) ile Kalaycı (2010) haber takibi ve bireysel işler faktörlerinde de erkekler lehine anlamlı farklılık tespit etmiştir. Ayrıca Küsmez (2018) tarafından gerçekleştirilen araştırmada da erkeklerin iş doyumlarının daha yüksek olduğu saptanmıştır. Bu doğrultuda, haber takibi, bireysel işler ve iş doyumunda cinsiyet bakımından literatürde farklı bulguların yer aldığ1 söylenebilir. Bu farklılıkların nedeni, örneklemlerin yapısal farklılıkları, dönemsel şartlardaki farklılıklar ve günümüzde iş yerinde internet kullanımının artık normal bir davranış olarak görülüyor olması olabilir.

Medeni duruma göre yapılan farklılık analizinde, yalnızca arama yapma faktöründe bekâkatılımcılar lehine anlamlı farklılığa rastlanmıştır. Küsmez (2018) tarafından yapılan çalışmada da arama yapma faktöründe bekâlar lehine anlamlı farklılık saptanmıştır. Ayrıca Küsmez'in (2018) çalışmasında iş doyumunda medeni duruma göre anlamlı bir farklılık tespit edilmemiştir. Buna göre, araştırmada elde edilen bu bulguların, literatürdeki önceki çalışmaların bulgularıyla benzerlik gösterdiği söylenebilir. Ancak Küsmez (2018) tarafından yapılan çalışmada ayrıca haber takibi ve bireysel işler faktörlerinde de bekâlar lehine anlamlı farklılıklara rastlanmıştır. Bu doğrultuda, haber takibi ve bireysel işler faktörlerinde medeni durum açısından literatürde farklı bulguların yer aldığı söylenebilir. Bu farklılıkların nedeni, örneklemlerin yapısal farklılıkları, dönemsel şartlardaki farklılıklar ve günümüzde iş yerinde internet kullanımının artık normal bir davranış olarak görülüyor olması olabilir.

Yaş grubuna göre yapılan farklılık analizinde, iş doyumu ile arama yapma faktörlerinde anlamlı farklılıklara rastlanmış ve 45-54 yaş grubundakilerin diğer yaş grubunda olanlara kıyasla daha yüksek iş doyumuna sahip oldukları; ayrıca 18-25 yaş grubundakilerin 45-54 yaş grubundakilere kıyasla internette daha fazla arama yaptıkları tespit edilmiştir. Bu durum, gençlerde internet kullanımının daha yaygın olması ile açıklanabilir. Mastrangelo vd. (2006) genç çalışanların önemli sanal kaytarma davranışlarının daha yüksek düzeyde olduğunu belirtmiştir. Ayrıca Örücü ve Yıldız (2014) hem önemli hem de önemsiz sanal kaytarma davranışının genç çalışanların lehine farklılaştığı bulgusu elde edilmiştir. Literatürdeki bu bulgu, çalışmada elde edilen bulgu ile paralellik göstermektedir. Tutcu (2018) tarafından yapılan çalışmada 54 ve üzeri yaş grubundakilerin gençlere kıyasla daha yüksek iş doyumuna sahip oldukları tespit edilmiştir. Literatürdeki bu bulgu, çalışmada iş doyumuna ilişkin elde edilen bulgu ile farklılığa sahiptir. Bu farklılığın nedeni, örneklemlerin yapısal farklılıklarından kaynaklanıyor olabilir. Zira Tutcu (2018) tarafından yapılan çalışmada öğretmenler örneklemi oluştururken, bu çalışmada ise örneklem özel sektör çalışanlarından oluşmaktadır. Araştırmada ayrıca haber takibi ve bireysel işler faktörlerinde yaş grubu için anlamlı bir farklılık tespit edilmemiştir. Bu durumun nedeni, günümüzde iş yerinde internet kullanımının artık normal bir davranış olarak görülüyor olması olabilir.

Eğitim düzeyine göre yapılan farklılık analizinde, arama yapma, bireysel işler, sosyalleşme ve haber takibi faktörlerinde anlamlı farklılıklara rastlanmış olup; lisans ve lisansüstü mezunlarının, lise mezunlarına kıyasla internette daha çok arama yaptıkları, bireysel işleriyle daha fazla ilgilendikleri, daha fazla sosyal medyada vakit geçirdikleri; ayrıca lisans mezunlarının lise ve lisansüstü mezunlarına kıyasla internette daha fazla haber 
takibi yaptıkları tespit edilmiştir. Bu durum, eğitim seviyesi daha yüksek olan çalışanların iş yerinde interneti daha fazla kullandıklarını göstermektedir. Bu bulgu, literatürdeki önceki çalışmaların bulgularıyla paralelliğe sahiptir (Örücü ve Yıldız, 2014; Özkalp vd., 2012; Atkin vd., 1998; Garrett ve Dangizer, 2008). Araştırmada ayrıca iş doyumunda eğitim düzeyi için anlamlı bir farklılık tespit edilmemiştir. Bu durumun nedeni, eğitim düzeyi her ne olursa olsun özel sektörde çalışanların işlerinden benzer biçimde tatmin olmalarıyla açıklanabilir. Tutcu (2018) tarafından yapılan çalışmada da eğitim durumuna göre iş doyumunda anlamlı bir farklılık tespit edilmemiş olup, bu durum iki çalışmada elde edilen bu bulguların paralellik arz ettiğini göstermektedir.

Aylık gelir durumuna göre yapılan farklılık analizinde, yalnızca iş doyumunda anlamlı farklılığa rastlanmıştır. Buna göre, aylık gelir durumu 5.000 TL'nin üzerinde olanların, 5.000 TL'nin altında olanlara kıyasla iş doyumlarının daha yüksek olduğu tespit edilmiştir. Tutcu (2018) tarafından yapılan çalışmada ise iş doyumunun aylık gelire göre farklılaşmadığı bulgusu elde edilmiştir. Bu doğrultuda, bu araştırma bulgusu ile literatürdeki önceki çalışmaların bulgularının farklılık arz ettiği söylenebilir. Bu farklılığın nedeni, örneklemlerin yapısından kaynaklanıyor olabilir. Bunun yanı sıra, arama yapma, bireysel işler, sosyalleşme ve haber takibi faktörlerinde anlamlı farklılıklara rastlanmamıştır. Bu durumun nedeni, günümüzde iş yerinde internet üzerinden arama yapma, haber takip etme, sosyal medya araçlarını kullanma ve internette bireysel işlerle uğraşılması gibi davranışların artık normal bir davranış olarak görülüyor olması olabilir.

Sonuç olarak, özel sektör çalışanlarının iş doyumlarının sanal kaytarma davranışını anlamlı olarak etkilemediği, ayrıca sanal kaytarma davranışı faktörleri ile iş doyumunun çeşitli demografik özelliklere göre farklılık gösterdiği bulguları elde edilmiştir. Bu bağlamda, çalışma kapsamında literatüre önemli katkılar sağlayacak bulguların elde edilmiş olduğu söylenebilir. Zira sanal kaytarma ile iş doyumu ilişkisine yönelik ve sanal kaytarma faktörlerinin demografik özelliklere göre farklılaşma durumuyla ilgili az sayıda araştırma literatürde yer almaktadır.

Çalışma çerçevesinde iş doyumunun sanal kaytarmayı anlamlı olarak etkilemediği tespit edilmiştir. Bu bağlamda, Gaziantep'teki özel sektör firmalarının yöneticilerinin, sanal kaytarma davranışını azaltmak üzere çalışanları ile daha fazla ilgilenmeleri, ayrıca iş doyumlarını yükseltici birtakım stratejiler uygulamaları gerektiği söylenebilir. İleride yapılabilecek olan araştırmalarda sanal kaytarma davranışının farklı kavramlarla (örgütsel bağlllık, örgütsel vatandaşlık, tükenmişlik, örgütsel stres, örgütsel vatandaşlık, mobbing vb.) olan ilişkileri incelenebilir. Bunun yanı sıra farklı şehirlerde ve farklı örneklem grupları üzerinde iş doyumu ile sanal kaytarma davranışı ilişkisini tespit etmeye ilişkin çeşitli çalışmalar gerçekleştirilebilir.

\section{KAYNAKÇA}

Alias, M., Mohd-Rasdi, R., Ismail, M., \& Abu Samah, B. (2013). Predictors of workplace deviant behaviour: HRD agenda for Malaysian support personnel. European Journal of Training and Development, (37), 161182.

Anandarajan, M., Devine, P., \& Simmers, C. A. (2004). A multidimensional scaling approach to personal web usage in the workplace, in Personal web usage in the workplace: a guide to effective human resources management, M. Anandarajan \& C. A. Simmers (Eds.), 61-78. U.S.A.: Information Science Publishing.

Aşık, N. A. (2010). Çalışanların iş doyumunu etkileyen bireysel ve örgütsel faktörler ile sonuçlarına ilişkin kavramsal bir değerlendirme. Türk İdare Dergisi, (467), 31-51.

Atkin, D., Jeffres, L., \& Neuendorf, K. (1998). Understanding internet adoption as telecommunications behavior. Journal of Broadcasting \& Electronic Media, 42(4), 475-490.

Barlı, Ö. (2008). Davranış bilimleri ve örgütlerde davranış, 3. Basım. Ankara: Aktif Yayınevi.

Blanchard, A., \& Henle, C. (2008). Correlates of different forms of cyberloafing: The role of norms and external locus of control. Computers in Human Behavior, 24(3), 1067-1084.

Brayfield, A. H., \& Rothe, H. F. (1951). An index of job satisfaction. Journal of Applied Psychology, 35(5), 307-311

Chaudhuri, M. R. (2014). Job satisfaction: The eventual smidgeon for occupational consummation and contentment in profession. DLSU Business \& Economics Review, 24(1), 73-83. 
Chomal, N., \& Baruah, P. (2014). Performance linked reward and job satisfaction: Banking sector. SCMS Journal of Indian Management, 11(4), 53-60.

Cook, A. W. (2017). Cyberloafing, job satisfaction, and employee productivity: A quantitative study. Unpublished Doctoral Dissertation. Northcentral University School of Business and Technology Management.

Çavuşoğlu, S., \& Palamutçuoğlu, B. T. (2017). İş tatmininin sanal kaytarma üzerindeki etkisi. Mehmet Akif Ersoy Üniversitesi Sosyal Bilimler Enstitüsü Dergisi, 9(19), 430-444.

Çivilidağ, A. (2017). İş yaşamında sanal kaytarmanın iş stresi, iş doyumu ile ilişkisi üzerine bir araştırma. Akademik Bakış Uluslararası Hakemli Sosyal Bilimler Dergisi, (59), 355-373.

Folami, L. B., Asare, K., Kwesiga, E., \& Bline, D. (2014). The impact of job satisfaction and organizational context variables on organizational commitment. International Journal of Business $\mathcal{E}$ Public Administration, 11(1), 1-18.

Garrett, R. K., \& Danziger, J. N. (2008). Disaffection or expected outcomes: Understanding personal internet use during work. Journal of Computer-Mediated Communication, 13(4), 937-958.

Greenberg, J., \& Baron, R. A. (2003). Behavior in organization: Understanding and managing the human side of organization, 8th Ed. New Jersey: Prentice Hall.

İnce, M., \& Gül, H. (2011). The relation of cyber slacking behaviors with various organizational outputs: Example of Karamanoğlu Mehmetbey University. European Journal of Scientific Research, 52(4), 507-527.

Jackson, L. A., Ervin, K. S., Gardner, P. D., \& Schmitt, N. (2001). Gender and the internet: Women communicating and men searching. Sex Roles, (44), 363-379.

Kalaycı, E. (2010). Üniversite öğrencilerinin siberaylaklık davranışları ile öz düzenleme stratejileri arasındaki ilişkinin incelenmesi. Yayınlanmış Yüksek Lisans Tezi. Hacettepe Üniversitesi FBE, Ankara.

Kuşluvan, Z., \& Kuşluvan, S. (2005). Otel işletmelerinde iş ve işletme ile ilgili faktörlerin işgören tatmini üzerindeki görece etkisi: Nevşehir örneği. Anatolia Turizm Araştırmaları Dergisi, 16(2), 183-203.

Küsmez, D. (2018). Using internet during work hours and its relation with employee attitudes. Unpublished Master Thesis. Bahçeşehir University SBE, İstanbul.

Liberman, B., Seidman, G., Mckenna, K. Y., \& Buffardi, L. E. (2011). Employee job attitudes and organizational characteristics as predictors of cyberloafing. Computers in Human Behavior, 27(6), 2192-2199.

Lim, V. K. (2002). The IT way of loafing on the job: Cyberloafing, neutralizing and organizational justice. Journal of Organizational Behavior, 23(5), 675-694.

Lim, V. K., \& Teo, T. S. H. (2005). Prevalence, Perceived seriousness, justification and regulation of cyberloafing in Singapore: An exploratory study. Information \& Management, (42), 1081-1093.

Locke, E. A. (1968). What is job satisfaction? Speech presented at the American Psychological Association Convention, August 30-September 3, American Psychological Association, San Francisco, California.

Manrique de Lara, P. Z., Tacoronte, D. V., Ding, J. M. T. (2006). Do current anti-cyberloafing disciplinary practices have a replica in research findings? A study of the effects of coercive strategies on workplace internet misuse. Internet Research, 16(4), 450-467.

Mastrangelo, P. M., Everton, W., \& Jolton, J. A. (2006). Personal use of work computers: Distraction versus destruction. CyberPsychology \& Behavior, (9), 730-741.

Özkalp, E., Aydın, U., \& Tekeli, S. (2012). Sapkın örgütsel davranışlar ve çalışma yaşamında yeni bir olgu: Sanal kaytarma (cyberloafing) ve iş ilişkilerine etkileri. Çimento İşveren Sendikası Dergisi, 26(2), 18-33.

Örücü, E., \& Yıldız, H. (2014). İşyerinde kişisel internet ve teknoloji kullanımı: Sanal kaytarma. Ege Akademik Bakış Dergisi, 14(1), 99-114.

Özler, D. E., \& Polat, G. (2012). Cyberloafing phenomenon in organizations: Determinants and impacts. International Journal of Business and eGoverment Studies, 4(2), 1-15. 
C. Ş. Eyel - A. Tutcu 12/4 (2020) 3596-3612

Robbins, S. P., \& Judge, T. A. (2013). Örgütsel davranış, İ. Erdem (Çev.), 14. Basım. Ankara: Nobel Akademik Yayıncilik.

Stanton, J. M. (2002). Company profile of the frequent Internet user. Communications of the ACM, 45(1), 55-59.

Şimşek, M. S., Akgemci, T., \& Çelik, A. (2007). Davranış bilimlerine giriş ve örgütlerde davranış. Ankara: Eğitim Kitabevi Yayınları.

Taş, Y. (2011). İş tatmini ve bilgi paylaşımı düzeyinin duygusal bağlılığa etkisi: Kocaeli Üniversitesi Araştırma ve Uygulama Hastanesinde bir araştırma. Kocaeli Üniversitesi Sosyal Bilimler Enstitüsü Dergisi, 21(1), 117-131.

Tutcu, A. (2018). Duygusal sermayenin iş ve yaşam doyumu üzerine etkisine ilişkin duyuşsal iyilik algısının aracılık etkisi. Yayınlanmamış Doktora Tezi. Hasan Kalyoncu Üniversitesi SBE, Gaziantep.

Türk, M. S. (2007). Örgüt kültürü ve iş tatmini. Ankara: Gazi Kitapevi.

Ünal, Ö. F., \& Tekdemir, S. (2015). Sanal kaytarma: Bir kamu kurumunda ampirik bir araştırma. Süleyman Demirel Üniversitesi, İktisadi ve İdari Bilimler Fakültesi Dergisi, 20(2), 95-118.

Vitak, J., Crouse, J., \& LaRose, R. (2011). Personal internet use at work: Understanding cyberslacking. Computers in Human Behavior, (27), 1751-1759.

Weatherbee, T. G. (2010). Counterproductive use of technology at work: Information \& communications technologies and cyberdeviancy. Human Resource Management Review, 20(1), 35-44.

Yaşar, S. (2013). Üniversite öğrencilerinin denetim odă̆ı ve bilgisayar laboratuvarına yönelik tutumlarının siberaylaklık davranışlarına etkisi. Yayınlanmamış Yüksek Lisans Tezi. Hacettepe Üniversitesi FBE, Ankara.

Yıldırım, F. (2018). Tükenmişlik düzeyinin sanal kaytarma davranışına etkisinde iş doyumunun aracılık rolü. Gazi Üniversitesi Sosyal Bilimler Dergisi, 5(13), 302-313.

Yılmaz, B. (2018). Seyahat acentesi çalışanlarının sanal kaytarma davranışları, iş motivasyonu ve iş tatmini arasındaki ilişkilerin incelenmesi. Yayınlanmamış Yüksek Lisans Tezi. Eskişehir Osmangazi Üniversitesi Sosyal Bilimler Enstitüsü, Eskişehir.

Yoon, J., \& Thye, S. R. (2002). A dual process model of organizationalcommitment: job satisfaction and organizationalsupport. Work and Occupations, 29(1), 97-124. 